\title{
Experimental animal models of drug-induced sensorineural hearing loss: a narrative review
}

\author{
Xuexin Lin ${ }^{1}$, Jia Luo ${ }^{1}$, Jingqian Tan ${ }^{2}$, Luoying Yang ${ }^{1}$, Mitian Wang ${ }^{3}$, Peng Li $^{1 \wedge}$ \\ ${ }^{1}$ Department of Otolaryngology Head and Neck Surgery, The Third Affiliated Hospital of Sun Yat-sen University, Guangzhou, China; ${ }^{2}$ Department \\ of Otolaryngology Head and Neck Surgery, The Eighth Affiliated Hospital of Sun Yat-sen University, Shenzhen, China; ${ }^{3}$ Department of \\ Otolaryngology Head and Neck Surgery, The Third Affiliated Hospital of Sun Yat-sen University Yuedong Hospital, Meizhou, China \\ Contributions: (I) Conception and design: X Lin, J Luo; (II) Administrative support: None; (III) Provision of study materials or patients: None; (IV) \\ Collection and assembly of data: X Lin, J Luo; (V) Data analysis and interpretation: All authors; (VI) Manuscript writing: All authors; (VII) Final \\ approval of manuscript: All authors. \\ Correspondence to: Peng Li, MD. Department of Otolaryngology Head and Neck Surgery, the Third Affiliated Hospital of Sun Yat-sen University, 600 \\ Tianhe Road, Guangzhou 510630, China. Email: 1p76@163.net.
}

\begin{abstract}
Objective: This narrative review describes experimental animal models of sensorineural hearing loss (SNHL) caused by ototoxic agents.

Background: SNHL primarily results from damage to the sensory organ within the inner ear or the vestibulocochlear nerve (cranial nerve VIII). The main etiology of SNHL includes genetic diseases, presbycusis, ototoxic agents, infection, and noise exposure. Animal models with functional and anatomic damage to the sensory organ within the inner ear or the vestibulocochlear nerve mimicking the damage seen in humans are employed to explore the mechanism and potential treatment of SNHL. These animal models of SNHL are commonly established using ototoxic agents.

Methods: A literature search of PubMed, Embase, and Web of Science was performed for research articles on hearing loss and ototoxic agents in animal models of hearing loss.

Conclusions: Common ototoxic medications such as aminoglycoside antibiotics (AABs) and platinum antitumor drugs are extensively used to induce SNHL in experimental animals. The effect of ototoxic agents in vivo is influenced by the chemical mechanisms of the ototoxic agents, the species of animal, routes of administration of the ototoxic agents, and the dosage of ototoxic agents. Animal models of drug-induced SNHL contribute to understanding the hearing mechanism and reveal the function of different parts of the auditory system in humans.
\end{abstract}

Keywords: Animal model; sensorineural hearing loss (SNHL); ototoxic agent

Submitted May 16, 2021. Accepted for publication Aug 16, 2021.

doi: $10.21037 / \mathrm{atm}-21-2508$

View this article at: https://dx.doi.org/10.21037/atm-21-2508

\section{Introduction}

Approximately 466 million people worldwide experience hearing loss (World Health Organization, Deafness and Hearing Loss, 2019). Sensorineural hearing loss (SNHL) is the most common form of hearing loss. Individuals with hearing loss may experience impaired language development and suffer from depression $(1,2)$. Understanding the mechanism of SNHL can improve clinical diagnosis, treatment, and prevention. Animal models mimicking the auditory impairments of SNHL are important in understanding the mechanism of SNHL in humans.

Common etiological factors of SNHL include genetic diseases, presbycusis, noise exposure, inflammation, ototoxic

\footnotetext{
$\wedge$ ORCID: 0000-0001-5516-5812.
} 
drugs, and chemicals. The pathological features of SNHL include damage to the cochlea, vestibulocochlear nerve (cranial nerve VIII), or the central processing center of the brain. The organ most regularly damaged by ototoxic drugs is the cochlea. The cochlea is a snail-shaped bony canal divided into three chambers known as the scala vestibuli, scala media, and scala tympani. The scala vestibuli and scala tympani are filled with perilymph, a solution rich in sodium (3). The scala media contains endolymph, a solution rich in potassium (4). The upper border of scala media is Reissner's membrane, and the lateral wall is composed of the spiral ligament, the thickened periosteum, and the stria vascularis, the upper portion of the spiral ligament containing an abundance of blood vessels. And the stria vascularis is mainly composed of three layers of epithelial cells known as marginal cells, intermediate cells, and basal cells. The intercellular space of the stria vascularis contains a rich capillary network, which is a component of the cochlear blood labyrinth barrier. The lower wall of the scala media is composed of the spiral edge and basilar membrane formed by the thickening of the periosteum on the spiral plate of bone. The Corti organ is located on the basilar membrane and consists of hair cells, supporting cells, and the tectorial membrane (5). One row of inner hair cells (IHCs) is located near the modiolus, and 3 rows of outer hair cells (OHCs) are located near the lateral wall of the cochlea. Spiral ganglion neurons (SGNs) are classified into types I and II, most of which are type I. The spiral ganglion is located in the spiral canal of the modiolus. One end of the nerve fiber of the spiral ganglion functions to establish synaptic connections with hair cells, while the opposite end extends into the central canal of the cochlear modiolus to form an acoustic nerve tract. This extension continues into the brain through the internal acoustic meatus and further in to reach the cochlear nucleus of the brainstem. When sound vibrates the tympanic membrane, the vibrations travel to the oval window through the ossicular chain, causing the perilymph and endolymph vibration, leading to the vibration of the basilar membrane. The basilar membrane and tectum, attached to the spiral plate of bone, move up and down along different modiolus. A shearing motion occurs between the tectum and the reticular plate, which causes the stereocilium of hair cells to bend or deflect. At this time, the potassium channel of the hair cells is open so the potassium ions in the endolymph can flow into the hair cells and cause depolarization. This depolarization leads to the opening of intracellular calcium channels, which allows calcium ions to flow into cells and stimulates hair cells to release neurotransmitters, causing nerve impulses at the cochlear nerve endings, which are attached to the bottom of hair cells. These nerve impulses are transmitted to the auditory cortex through the central conduction pathway to produce the sensation of hearing.

A common method of establishing animal models of SNHL with different damage characteristics is through ototoxic drugs. There are over 150 ototoxic agents, with aminoglycoside antibiotics (AABs), loop diuretics, and antitumor drugs being the most frequently used (6). Due to the various effects of ototoxic agents, those that induce specific inner ears lesions are often chosen for use in hearing research.

Methods of auditory assessment are predominantly comprised of cochlear microphonics (CM), summating potential (SP), auditory brainstem response (ABR), distortion product otoacoustic emissions (DPOAEs), compound action potentials (CAPs), and histological evaluation. $\mathrm{CM}$ involves a current primarily generated by the receptor currents of OHCs and can mirror the condition of OHCs (7). SP is a direct potential generated by the movement of the hair cells and basilar membrane (8-10). CAPs originate from the synchronous discharge of many primary afferent fibers in the auditory nerve and represent the total discharge of many single auditory neurons. CAPs are the compound nerve action potential of the eighth pair of brain nerve terminals (11). The main source of otoacoustic emissions in mammals is OHCs. These otoacoustic emissions can reflect their survival and mirror their functional status (12). The ABR reflects the transmission of auditory impulses induced by sound stimulation through the brainstem auditory pathway (13). The effectiveness of these methods in rodents was tested in studies (11,14-20).

The animal models of drug-induced SNHL can not only be used to study the ototoxic mechanisms of these drugs, but can also be used to study the relevant pathophysiological mechanisms of the lesions of the cochlear structures. This review introduces the commonly used animal models of SNHL induced by ototoxic drugs.

We present the following article in accordance with the Narrative Review reporting checklist (available at https:// dx.doi.org/10.21037/atm-21-2508).

\section{Methods}

We conducted a search of the PubMed, Embase, and Web of Science databases using the keywords "sensorineural hearing loss", "inner ear", "cochlea*”, "animal model”, 
"ototoxicity", "ototoxic agents", "ototoxic drugs", "Aminoglycoside antibiotics", "gentamicin", "kanamycin", "streptomycin”, "amikacin”, "tobramycin”, "neomycin”, "platinum”, "cisplatin", “carboplatin”, "oxaliplatin", "Doxorubicin", "Adriamycin", "aromatic solvent", "toluene", "ethylbenzene", "ouabain", "glutamic", "kainic acid", "2-hydroxypropyl- $\beta$-cyclodextrin", "HP $\beta C D$ ", "heavy metals", "manganese", "mercury", "cobalt", "cadmium", and "lead". By browsing the title and/or abstract, a total of 4,565 original articles and review articles related to ototoxic agent-induced SNHL and published in English between January 1980 and February 2021 were collected. Articles that were not animal experiments that did not focus on cochlear lesions and lacked morphological and/or functional tests were excluded. Relevant information was extracted for this review from the 375 articles remaining after applying the exclusion criteria.

\section{Ototoxic agents}

\section{$A A B s$}

AABs are widely used in clinical practice; and include kanamycin, gentamicin, amikacin, neomycin, and tobramycin. The ototoxicity of AABs has long been confirmed by many studies (21-23). Long-term clinical therapy using these ototoxic medications is associated with irreversible hearing loss at high frequencies (24). Previous research has reported that gentamicin, streptomycin, and tobramycin are mainly vestibulotoxic; while kanamycin, amikacin, and neomycin are mostly cochleotoxic $(25,26)$. Studies have demonstrated that AABs can pass through the blood-labyrinthine barrier (BLB) to the endolymph. The AABs subsequently enter hair cells through mechanoelectrical transducer (MET) channels or endocytosis (27-29). $\mathrm{AABs}$ can inhibit depolarization of the hair cells and alter the concentration of perilymph ions, resulting in damage to the hair cell bundles, which causes permanent hearing loss (30). Also, AABs can produce free radicals and reactive oxygen species, which ultimately cause caspase activation and apoptosis (31-33).

Animals play an important role in establishing models of SNHL. Different species may present with different lesions following identical treatment. For example, the given dose of aminoglycosides that induces cochlear hair cell loss in guinea pigs and chinchillas does not have the same effects on inducing cochlear hair cell loss in mature mice (34). Only a small amount of hair cell damage was induced in the cochleae of adult mice and rats when administered conventional doses of gentamicin or kanamycin. Similar results were found when the same animals were administered high dosages that were close to a lethal concentration (35). The resistance to AABs in adult mice and rats may be attributed to the rapid clearance of the drugs in serum, suggesting the need to increase the dosage $(36,37)$. The clearance half-life of kanamycin in 12-day-old rats was 2.5 times longer than in 25 -day-old rats (36). Some experiments have attempted to use different dosages and frequencies of administration to induce auditory system lesions. One study administered a high dose $(800 \mathrm{mg} / \mathrm{kg})$ of kanamycin twice daily for 14 consecutive days and induced heavy hair cell loss in mice and rats (35). Concomitant administration of an additional ototoxic drug, such as a platinum anticancer drug, can enhance ototoxicity (38). Schweitzer et al. found that a combined cisplatin and kanamycin treatment resulted in more significant $\mathrm{OHC}$ loss and ABR threshold shifts than cisplatin treatment (38). In addition, concomitant loop diuretics have been shown to increase the ototoxic effect of AABs on the cochlea (39). A single subcutaneous injection of $1 \mathrm{mg} / \mathrm{g}$ body weight of kanamycin followed 40 minutes later by an intraperitoneal injection of $0.05 \mathrm{mg} / \mathrm{g}$ body weight of bumetanide resulted in almost the entire loss of OHCs within 48 hours (39). Loop diuretics include furosemide, ethacrynic acid, bumetanide, and torsemide (40). By blocking the capillaries on the lateral cochlear wall and inhibiting the arterial blood flow to the stria vascularis and spiral ligament, loop diuretics can cause ischemia and hypoxia in the stria vascularis epithelial cells and thus destruct the BLB (41). Combination therapy of $\mathrm{AABs}$ and loop diuretics can lead to irreversible deafness. For instance, a single dose of kanamycin (400-500 $\mathrm{mg} / \mathrm{kg}$ ) by subcutaneous injection accompanied by a dose of furosemide $(100 \mathrm{mg} / \mathrm{kg})$ by intraperitoneal injection can lead to permanent hearing loss in gerbils, with significant loss of both OHCs and IHCs as well as the injury of SGNs (42). In conclusion, animal species and dosage regimens are important factors in establishing AABs-induced animal models of SNHL, and selecting the appropriate animal species and adjusting dosage can obtain the expected model of specific lesions (Table 1) (39,43-54).

\section{Platinum antitumor drugs}

Cisplatin and carboplatin are robust antitumor drugs, but they can also be ototoxic or neurotoxic (55-64). Cisplatin enters hair cells mainly through copper transport channels 
Table 1 Animal models of SNHL induced by aminoglycoside antibiotics

\begin{tabular}{|c|c|c|c|c|c|c|c|}
\hline Drug & Animal & Route & Dose & Schedule & Duration & Ototoxicity & Reference \\
\hline kana & Mouse & s.c. & $800 \mathrm{mg} / \mathrm{kg}$ & $2 x$ daily & 15 days & $\begin{array}{l}\text { Loss of OHCs. DPOAE } \\
\text { thresholds shifted } \\
\text { and ABR thresholds } \\
\text { increased }\end{array}$ & $(44,45)$ \\
\hline Kana + furo & Mouse & s.c. + i.p. & $1 \mathrm{~g} / \mathrm{kg}+300 \mathrm{mg} / \mathrm{kg}$ & Single-dose & 1 day & $\begin{array}{l}\text { Loss of OHCs and } \\
\text { IHCs }\end{array}$ & (46) \\
\hline Kana + furo & Rat & RWN & $200 \mathrm{mg} / \mathrm{mL}+50 \mathrm{mg} / \mathrm{mL}$ & Single-dose & 1 day & $\begin{array}{l}\text { ABR thresholds } \\
\text { increased at } 8-40 \mathrm{kHz}\end{array}$ & (47) \\
\hline Kana + furo & Mouse & i.p. & $900 \mathrm{mg} / \mathrm{kg}+50 \mathrm{mg} / \mathrm{kg}$ & $2 \times$ daily & 15 days & $\begin{array}{l}\text { Loss of OHCs and } \\
\text { IHCs, and SGNs } \\
\text { damaged. ABR } \\
\text { thresholds increased to } \\
20 \mathrm{~dB} \text { at } 16 \mathrm{kHz} \text {, } \\
35 \mathrm{~dB} \text { at } 22 \mathrm{kHz} \text {, and } \\
\text { to maximum at } 32 \mathrm{kHz}\end{array}$ & (49) \\
\hline Gent & Mouse & i.p. & $200 \mathrm{mg} / \mathrm{kg}$ & $3 \times$ per week & 1 week & $\begin{array}{l}\text { ABR threshold } \\
\text { increased }\end{array}$ & (50) \\
\hline Amik & Rat & i.m. & $600 \mathrm{mg} / \mathrm{kg}$ & $1 \times$ daily & 15 days & $\begin{array}{l}\text { Reduced amplitude of } \\
\text { DPOAE }\end{array}$ & (54) \\
\hline
\end{tabular}

SNHL, sensorineural hearing loss; kana, kanamycin; amik, amikacin; gent, gentamycin; neo, neomycin; bume, bumetanide; furo, furosemide; etha, ethacrynic acid; i.v., intraveneous; i.m., intramuscular; s.c., subcutaneous; i.p., intraperitoneal; RWN, round window niche; RWM, round window membrane; i.t., intratympanic; OHCs, outer hair cells; IHCs, inner hair cells; SGNs, spiral ganglion neurons; DPOAE, distortion product otoacoustic emission; ABR, auditory brainstem response; CAP, compound action potential.

to induce oxidative stress, leading to increased reactive oxygen species and inner ear damage $(65,66)$. Cisplatin also stimulates the cell death factor receptor, which is located on the surface of the hair cell membrane, to activate caspase- 8 and its downstream caspase- 3 causing programmed death of hair cells (67). Experiments have indicated that cisplatin mainly injures cochlear hair cells, with OHCs being more susceptible than IHCs; while carboplatin chiefly affects cochlear IHCs, cochlear type I afferent neurons, and vestibular type I hair cells $(56,68)$. Studies demonstrated that a single intraperitoneal dose (commonly $12-16 \mathrm{mg} / \mathrm{kg}$ ) of cisplatin in rats, mice, or guinea pigs could cause time- 
Table 2 Animal models of SNHL induced by platinum antitumor drugs

\begin{tabular}{|c|c|c|c|c|c|c|c|}
\hline Drug & Animal & Route & Dose & Schedule & Duration & Ototoxicity & Reference \\
\hline Cis & Guinea pig & i.p. & $12 \mathrm{mg} / \mathrm{kg}$ & Single-dose & 1 day & $\begin{array}{l}\text { OHCs partially lost throughout the cochlea. } \\
\text { ABR threshold shifted }\end{array}$ & $(58,59)$ \\
\hline Cis & Fischer $344 / \mathrm{NHsd}$ rat & i.p. & 12 mg/kg & Single-dose & 1 day & $\begin{array}{l}\text { OHC loss increased from the apex to the } \\
\text { base. ABR thresholds increased }\end{array}$ & (60) \\
\hline Carb & Chinchilla & i.v. & $200 \mathrm{mg} / \mathrm{m}^{2}$ & Single-dose & 1 day & Loss of IHCs. ABR thresholds increased & (63) \\
\hline Carb & Chinchilla & i.p. & $75 \mathrm{mg} / \mathrm{kg}$ & Single-dose & 1 day & $\begin{array}{l}\text { Loss of } 40 \% \text { of IHCs. The amplitude of SP } \\
\text { and CAP declined }\end{array}$ & (64) \\
\hline
\end{tabular}

SNHL, sensorineural hearing loss; cis, cisplatin; carb, carboplatin; furo, furosemide i.v., intraveneous; i.p., intraperitoneal; OHCs, outer hair cells; IHCs, inner hair cells; ABR, auditory brainstem response; DPOAE, distortion product otoacoustic emission; CAP, compound action potential; SP, summating potential.

dependent damage of OHCs and the stria vascularis (Table 2) (56-60). Some studies also adopted regimens of lower single-dose multiple-administrations which resulted in low mortality rates (69). Death rates were lower in CBA/CaJ mice and C57BL/6J mice exposed to $48 \mathrm{mg} / \mathrm{kg}$ cisplatin and treated in 3 cycles of two $8 \mathrm{mg} / \mathrm{kg}$ doses every 10 days or 3 cycles of $4 \mathrm{mg} / \mathrm{kg}$ doses daily for 4 consecutive days, where each cycle was separated by 17 days than when exposed to three $16 \mathrm{mg} / \mathrm{kg}$ doses administered once per day, where each cycle was separated by 20 days (69).

Furthermore, the susceptibility to cisplatin ototoxicity in rats and mice can be affected by their circadian times, where the highest $\mathrm{ABR}$ threshold shift and the most severe $\mathrm{OHC}$ loss occur in the middle of the light circle $(70,71)$. Additionally, concomitant administration of noise exposure or loop diuretics can enhance the ototoxicity of cisplatin $(72,73)$. Cisplatin-treated rats were susceptible to noise exposure. Compared with cisplatin alone or noise exposure alone, a combination of the two resulted in rats showing greater threshold shifts and loss of OHCs (72). Guinea pigs treated with a co-administration of furosemide and cisplatin presented with more severe hearing loss and hair cell loss but lower mortality rates than those receiving cisplatin alone (73).
In contrast, carboplatin shows less ototoxicity to rodents, such as mice, than cisplatin (74). Gersten et al. treated mice with equimolar doses of cisplatin, oxaliplatin, and carboplatin; and found cisplatin-induced OHC-loss in only the middle and basal regions, elevated ABR thresholds across frequencies, and decreased DPOAE amplitudes (74). It is suggested that the lower ototoxicity of carboplatin and oxaliplatin is associated with a reduced uptake within the inner ear (74). Dose- and time-dependent oxidative damage of carboplatin to the cochlea in rats was reported $(61,75)$. The high doses (192 or $256 \mathrm{mg} / \mathrm{kg}$, intraperitoneal injection) of carboplatin led to increased cochlear lipid peroxidation and decreased antioxidant enzyme activity (75). Carboplatin caused elevated ABR threshold shifts, increased levels of nitric oxide, reactive oxygen species, increased manganese superoxide dismutase activity, and decreased antioxidant enzyme activity 4 days post-treatment in rats (61). A single intraperitoneal dose of carboplatin can induce selective damage of IHCs in chinchillas, providing an ideal IHC loss model (Table 2) (62-64,68,76-81). Additionally, studies have demonstrated that a low dose of carboplatin $(38-125 \mathrm{mg} / \mathrm{kg}$ ) selectively damages IHCs, while a high dose of carboplatin $(\geq 200 \mathrm{mg} / \mathrm{kg}$ ) causes extensive IHC loss and damage of 
OHCs in chinchillas (76).

Overall, cisplatin is more ototoxic than carboplatin and oxaliplatin; and platinum modeling is affected by dose, administration frequency, circadian rhythm, melanin, and drug combination.

\section{Doxorubicin}

DOXO is a common antitumor medication that intercalates into the DNA strand to interfere with DNA-directed mRNA synthesis (82). Studies have demonstrated that DOXO can cause demyelination secondary to Schwann cell degeneration (83), and thus utilized DOXO as an experimental demyelinating agent to create animal models of SGNs and auditory nerve demyelination (84). Intraneural injection of DOXO inside the internal auditory canal of chinchillas caused severe myelin injury in SGNs and in fibers of the Rosenthal's canal; and reduced ABR, CAP amplitude, and inferior colliculus-evoked potentials after 2 months. OHCs and IHCs were mostly intact, which was demonstrated by presenting regular cochleograms and the preservation of cubic DPOAEs and CMs (84). Hearing functional testing results of models demonstrating demyelination in SGNs and auditory nerve fibers (ANFs) exclusively resembled those of patients with auditory neuropathy, which is a type of SNHL resulting from auditory synaptopathy and neuropathy (85-87). Overall, the injection of DOXO through the internal auditory canal provides animal models demonstrating the demyelination of auditory nerves without damaging cochlear hair cells.

\section{Aromatic solvents}

Aromatic solvents are widely used in industries such as plastics, textiles, and pharmaceuticals (88). Exposure to aromatic solvents like toluene, ethylbenzene, and styrene is ototoxic to both animals and humans (89-92). Studies have shown that ototoxic aromatic solvents mainly damage OHCs, with different degrees of ototoxicity for OHCs and IHCs (90,93-96). Rats were exposed to $1,750-2,000 \mathrm{ppm}$ toluene vapor for 6 consecutive weeks, resulting in OHC damage and preservation of IHCs (96). Studies have demonstrated that exposure to $2,500 \mathrm{ppm}$ toluene or $1,600 \mathrm{ppm}$ styrene for 8 hours/day for 5 days in rats can lead to a significantly increased auditory threshold, matching the lesions of OHC loss (97).

Additionally, rats exposed to ethylbenzene at $400 \mathrm{ppm}$ or $550 \mathrm{ppm}$ for 8 hours/day for 5 consecutive days exhibited reduced DPOAEs and high OHC loss after 3-6 weeks (98).
Studies have shown that chinchillas are less susceptible to toluene than mice and rats, which may be due to the higher amount of hepatic cytochrome P-450s and glutathione in the cochleae of chinchillas compared to rats and mice $(99,100)$. Although the underlying mechanism of ototoxicity is undetermined, findings suggest that aromatic solvents including toluene, ethylbenzene, and styrene are useful in inducing selective $\mathrm{OHC}$ loss. Moreover, mice and rats may be more suitable for models of toluene ototoxicity.

\section{Ouabain}

Ouabain is a kind of cardiac glycoside and can selectively inhibit the $\alpha$ subunit of the sodium-potassium adenosine triphosphatase $\left(\mathrm{Na}^{+} / \mathrm{K}^{+}\right.$-ATPase) (101). The $\mathrm{Na}^{+} / \mathrm{K}^{+}$ATPase consists of the 3 subunits, $\alpha, \beta$, and $\gamma$. Within the $\alpha$ subunit, the subunit $\alpha 3$ is abundant in spiral ganglion somata, the type I afferent ending, and the medial efferent endings (102). Studies have found that an intraperitoneal dose of $50 \mathrm{mg} / \mathrm{kg}$ or $10 \mathrm{mM}$ ouabain, or applying $5-40 \mu \mathrm{L}$ of a $1 \mathrm{mM}$ ouabain solution on round window niche (RWN) can selectively destroy cochlear type I spiral ganglion cells and their ANFs in experimental animals such as mice, gerbils, and rats (15,103-106). Experiments have shown that ouabain damages the spiral ganglion through mitochondrial apoptosis and by demyelination of ANFs (105). However, Hamada and Kimura found OHC degeneration, type I SGN loss, and edema of the stria vascularis in some severe cases after ouabain was applied on a round window membrane in guinea pigs (107).

Additionally, Schomann et al. applied ouabain on a round window niche and observed OHC loss in a dose-dependent manner, without edema in the stria vascularis (108). High doses of ouabain damaged type I spiral ganglion cells and their ANFs and hair cells, whereas low or medium doses did not damage cochlear hair cells. It is assumed that ouabain directly affects $\mathrm{Na}^{+} / \mathrm{K}^{+}$-ATPase in OHCs, and indirectly affects $\mathrm{OHCs}$ by changing the endolymph content; however, the mechanisms remain undetermined $(109,110)$. The selective damage to SGNs caused by low or medium dosages of ouabain suggests that the ouabain model is an effective model for research into of SGN death and SGN protection (111).

\section{Glutamic acid and Glutamate analogs}

Glutamate is released excessively in cochlear tissues during ischemia and noise injury (112). Excess glutamate can cause 
excitotoxicity. The mechanism of excitotoxicity involves increased activity in neurons, the maintenance of neurons' depolarization, and increased concentration of chloride ions in cells, which causes more calcium ions to flow in, thus increasing the osmotic pressure in cells. As water enters the cell, the tension of the cell membrane increases, and the cell lyses (113). The ionotropic receptors of glutamate are classified as $\mathrm{N}$-methyl-d-aspartate (NMDA), $\alpha$-amino3-hydroxy-5-methyl-4-isoxazolepropionate (AMPA), and kainite. AMPA receptors mainly mediate the rapid excitatory neurotransmission between IHCs and AFNs, and the late component of neurotransmission is mediated by NMDA and kainite (114). AMPA/kainite receptors are activated first and may play a role in synaptic transmission at low and moderate intensity. The NMDA receptor is activated by high-intensity sound (112). In cultured spiral ganglion explants, a high glutamate concentration in the synaptic cleft can cause swelling and collapse of the afferent nerve endings and damage to type I SGNs (115).

The glutamate toxicity-induced apoptosis in SGNs is initiated by apoptosis-inducing factors rather than caspase-3 (116). Kainic acid, a glutamate agonist, has been used to damage type I afferent nerve endings in animals. The swelling of afferent synapses was rapidly induced by low concentrations of kainic acid and high concentrations of kainic acid in the perilymph of chicken cochlea (117). The swelling of synapses damaged by the low concentrations of kainic acid disappeared, and the synaptic area returned to normal within 1 day, while the synapses damaged by the high concentrations of kainic acid were irreversibly damaged, and the number of spiral ganglion cells decreased. The morphology and function of hair cells in both groups were normal. Low doses of kainic acid applied to the round window of chinchillas also caused reversible damage to the postsynaptic terminals of the auditory nerve. Three- 5 days after treatment, the nerve endings underwent swelling, degeneration, and recovery (118). However, high concentrations of kainic acid-induced the loss of $34 \%$ of SGNs, with no toxic effect on cochlear hair cells or supporting cells (119). Henry et al. demonstrated that kainic acid caused a decrease in wave I amplitude of ABR, with waves II-V unaffected or slightly changed; suggesting that kainic acid can selectively damage the afferent neurons of the auditory nerve (120).

The glutamate analogs of SGNs can induce selective SGN loss in animal models to explore the causes of initial excitotoxic injury to the postsynaptic neuron of SNHL and the regeneration of afferent nerve terminals (118).

\section{2-Hydroxypropyl-ß-cyclodextrin}

$\mathrm{HP} \beta C D$ is a cholesterol-chelating agent used to solubilize lipophilic drugs and is employed to treat Parkinson's disease, atherosclerosis, and Niemann-Pick disease type C (121-124). It is reported to cause ototoxicity in cats and patients undergoing long-term therapies $(125,126)$. A single subcutaneous dose of HP $\beta C D(8,000 \mathrm{mg} / \mathrm{kg})$ in mice led to elevated ABR, the elimination of DPOAEs, and loss of OHCs in the basal half of the cochlea; without affecting IHCs after 1 week (127). In another study, HP $\beta C D$ was subcutaneously administered to rats at high doses of 2,000 or $4,000 \mathrm{mg} / \mathrm{kg}$, leading to remarkably reduced DPOAE amplitudes and loss of OHCs (128). Studies also indicated that when using a high dosage, the IHC loss and lesions in other cochlear tissues occurred 4-8weeks post-treatment $(129,130)$. The mechanisms of the selective damage to OHCs remain undetermined. One factor at plays may be that prestin, the $\mathrm{OHC}$ motor protein and the main component of the $\mathrm{OHC}$ lateral membrane, is sensitive to changes in cholesterol levels (131-133). Compared to AABs' protocols, HP $\beta C D$ seems to be a more effective agent to induce loss of OHCs selectively. HP $\beta C D$ requires only a single systemic administration to induce OHC loss in mice, and its systemic toxicity is low (121). A greater understanding of the pharmacokinetics and mechanism of HP $\beta C D$ can lead to its improved application in experimental hair cell ablation in research animals. Based on this research, HPßCD can induce OHC loss quickly and affect other cochlear sensory cells after weeks.

\section{Heavy metals}

In daily life, excess exposure to heavy metals such as manganese $(\mathrm{Mn})$, mercury $(\mathrm{Hg})$, cobalt $(\mathrm{Co})$, cadmium $(\mathrm{Cd})$, and lead $(\mathrm{Pb})$ in food or air can cause various organ toxicity effects. Studies found that heavy metals can damage cochlear structures and lead to SNHL (134-139). Research has demonstrated that heavy metals enter cells, including cochlea cells, through divalent metal transporter 1 (DMT1), zinc transporter ZIP8, and ZIP14 (140-145). Heavy metals mainly affect mitochondrion by inhibiting calcium uptake and enhancing calcium release, thus altering the mitochondrial permeability and causing a release of cytochrome c. Consequently, heavy metals can induce oxidative stress leading to cell death (146-148). In research into cochlear organotypic cultures, $\mathrm{Cd}$ can induce apoptosis in the OHCs and IHCs of rats in a time-dependent manner (135); Mn 
can induce time- and dose-dependent OHC, IHC, SGN, and ANF damage (149), where ANFs are more vulnerable to Mn than hair cells and IHCs are more susceptible to $\mathrm{Mn}$ than $\mathrm{OHCs}$ (138); $\mathrm{Hg}$ tends to affect sensory epithelium in the apical regions of the cochlea and seldom damages the basal regions (150); there is an increase in the damage caused by Co to OHCs, IHCs, and SGNs from the base to the apex of the cochlea as dose and time increase, and the OHCs are more vulnerable to Co damage than IHCs (139); and $\mathrm{Pb}$ primarily injures cochlear nerve fibers and SGNs, rather than hair cells (151). Experimental animals have been successfully used to investigate the ototoxicity of heavy metals. Rats co-administered $5 \mathrm{mg} / \mathrm{kg} \mathrm{CdCl}$ (i.p.) and $200 \mathrm{mg} / \mathrm{kg}$ furosemide (i.p.) showed damaged OHCs in the apical and middle cochlear regions, extensive loss of IHCs and $\mathrm{OHCs}$ in the basal turn, and significantly increased ABR thresholds after 1 week (152). However, oral administration of 30 to $300 \mu \mathrm{M} \mathrm{Cd}$ in adult CBA/CaJ mice for 11 weeks presented normal ABR thresholds (153). Rats exposed to $10 \mathrm{mg}$ Manganese chloride $\left(\mathrm{MnCl}_{2}\right)$ /liter water for 90 days showed no significant threshold shifts of DOPAE, CAP, and $\mathrm{ABR}$; while rats exposed to noise simultaneously presented threshold shifts (154). Mice treated with $1.0 \mathrm{mg} / \mathrm{kg}$ mercuric sulfide per day through gastric gavage for 7 consecutive days demonstrated in an elevation of ABR threshold and prolongation of interwave latencies I-V (155). C57BL/6 mice given $2 \mathrm{mM} \mathrm{Pb}$ in water for 28 days presented $8-12 \mathrm{~dB}$ shifts in ABR thresholds (156). Rats subjected to $4.0 \mathrm{mg} / \mathrm{kg}$ $\mathrm{Pb}$ acetate by gavage for 30 days demonstrated prolonged latencies of waves $\mathrm{I}-\mathrm{V}$ and increased wave amplitudes, implying the deterioration of the neural reflex and damaged hearing (157). In another experiment, guinea pigs treated with $\mathrm{Pb}(20 \mathrm{mg} / \mathrm{mL}$, i.p.) exhibited in $\mathrm{OHC}$ damage and elevated ABR thresholds (158). In conclusion, the animal models of SNHL induced by heavy metals were established using gavage, drinking water exposure, and intraperitoneal injection. Drinking water exposure required a long period.

\section{Discussion}

The hearing loss induced by ototoxic drugs can be avoided in the clinic. By establishing the animal model of druginduced hearing loss, we can not only study the damage mechanism of drugs but also improve treatment and prevent the occurrence of ototoxic deafness. In addition, animal models can also be used to explore the molecular mechanism of deafness, hair cell regeneration, and cochlear cell replantation.
We searched the literature for 8 kinds of toxic cochlear drugs and ototoxic chemicals that have been studied in auditory diseases. These included AABs, platinum antitumor drugs, doxorubicin (DOXO), aromatic solvent, ouabain, glutamic acid, and Glutamate analogs, 2-Hydroxypropyl- $\beta$ cyclodextrin (HP $\beta C D)$, and heavy metals. The tendency of these ototoxic agents to damage the cochlea can be divided into 3 types: the types which included those which tend to damage auditory hair cells, those which tend to damage SGNs and nerve fibers, and those which tend to damage auditory hair cells and neurons.

Among them, AABs damage both hair cells and SGNs. Cisplatin tends to damage cochlear hair cells, particularly OHCs; and carboplatin tends to damage IHCs and SGNs. DOXO can damage the myelin. Aromatic solvents and cyclodextrin can cause more damage to OHCs than IHCs. Ouabain tends to damage SGNs and auditory nerve myelin. Glutamate analogs damage afferent nerve endings. Heavy metals mostly damage nerves but also damage auditory hair cells.

The establishment of animal models of drug-induced hearing loss may be affected by animal selection, route of drug administration, and dosage regimen.

Animal selection is an important aspect of the study of drug-induced deafness. Animals most commonly used in hearing research include rodents, such as guinea pigs, mice, rats, chinchillas, and gerbils. The auditory anatomy of rodents, including cochlear turns, sensory hair cells, and central auditory system, is similar to humans $(159,160)$. Different animals have different auditory physiology and anatomical structure, thus providing different advantages in auditory research. The hearing frequency of mice, rats, and guinea pigs is $100 \mathrm{kHz}, 250 \mathrm{~Hz}$ to $80 \mathrm{kHz}$, and $150 \mathrm{~Hz}$ to $50 \mathrm{kHz}$. In chinchillas and gerbils, their hearing frequencies are $\sim 50 \mathrm{~Hz}$ to $33 \mathrm{kHz}$ and $100 \mathrm{~Hz}$ to $50 \mathrm{kHz}$, respectively; which demonstrates that the hearing range of chinchillas is closer to humans (who have a range of 20 to $20 \mathrm{kHz})(161-164)$.

Moreover, guinea pigs, chinchillas, and rats have bigger ear bulla, allowing for greater efficiency of procedures such as injection through the tympanic membrane, retroauricular sulcus, or semicircular canal. Additionally, animals showed different susceptibilities to ototoxic drugs, which affected the dosage regimen. For example, guinea pigs and chinchillas showed higher susceptibility to AABs, while adult rats and mice showed lower susceptibility. Although adult mice and rats are resistant to some ototoxic drugs, they are still widely used in studies of drug-induced hearing 
loss. Particularly mice, which possess various strains such as $\mathrm{C} 57 \mathrm{BL} / 6$ mice, $\mathrm{BALB} / \mathrm{c}$ mice, and $\mathrm{CBA} / \mathrm{CaJ}$ mice, and gene knockout varieties, allow research into hearing loss with certain lesions. C57BL/6J mice are also widely used as models of presbycusis due to their Ahl/Ahl2 genes which accelerate age-related hearing loss (20,165-171).

$\mathrm{CBA} / \mathrm{CaJ}$ mice show stable hearing thresholds in advanced age (12-18 months), so they are suitable for experiments involving chronic exposure to ototoxic agents (172). Solute Carrier Family 19 Member 2 (SLC19A2)-deficient mice showed selective loss of both IHCs and intact supporting cells around IHCs (173). Aside from rodents, zebrafish are increasingly used in hearing research, such as hair cell regeneration studies, due to the susceptibility of their sensory epithelial cells along the lateral line to toxic agents (174-176).

The route of drug administration is another important factor affecting the establishment of animal models. The majority of the drugs were delivered to the cochlea by systemic administration, including subcutaneous injection and intraperitoneal injection, local administration involving transtympanic injections, cochleostomy with perilymphatic perfusion, and the round window niche technique. The direct methods of cochlear medication can avoid systemic toxicity such as nephrotoxicity and peripheral neuropathy; and can avoid the BLB, which is conducive to a faster and greater accumulation of drugs that do not easily cross the BLB in the inner ear $(177,178)$. Nevertheless, local delivery requiring perforations of the tympanic membrane, or incisions behind the ear or on the retroauricular groove, need to be performed on large rodents such as rats, guinea pigs, chinchillas or gerbils; and may increase the risk of infection. the perforation of the tympanic membrane may affect the detection of auditory function in animals (179). Moreover, additional training is required to perform these operations.

Various drug dosage regimens are adopted to induce SNHL. These include increasing the dosages, which may increase the mortality rate of animals; prolonging the treatment duration by multiple administrations; combining administration of loop diuretics, such as furosemide and ethacrynic acid, which can open the BLB; combining administration with noise or another ototoxic drug.

\section{Conclusions}

Over 150 ototoxic agents have been reported to date. Common ototoxic medications such as AABs and platinum antitumor drugs are extensively used to induce SNHL in experimental animals. The effect of ototoxic agents in vivo is generally influenced by the chemical mechanisms of the agents themselves, type of anima, routes of drug administration, and drug dosage levels. Studies involving experimental animal models of SNHL explore the underlying mechanisms involved in drug-induced hearing loss to discover effective interventions for clinical practice.

\section{Acknowledgments}

Funding: This work was supported by the National Natural Science Foundation of China (No. 82071050); National Natural Science Foundation of China (No. 2020G2RPYMS12); and Science and Technology Planning Project of Guangzhou, China (No. 201803010093).

\section{Footnote}

Reporting Checklist: The authors have completed the Narrative Review reporting checklist. Available at https:// dx.doi.org/10.21037/atm-21-2508

Conflicts of Interest: All authors have completed the ICMJE uniform disclosure form (available at https://dx.doi. org/10.21037/atm-21-2508). The authors have no conflicts of interest to declare.

Ethical Statement: The authors are accountable for all aspects of the work in ensuring that questions related to the accuracy or integrity of any part of the work are appropriately investigated and resolved.

Open Access Statement: This is an Open Access article distributed in accordance with the Creative Commons Attribution-NonCommercial-NoDerivs 4.0 International License (CC BY-NC-ND 4.0), which permits the noncommercial replication and distribution of the article with the strict proviso that no changes or edits are made and the original work is properly cited (including links to both the formal publication through the relevant DOI and the license). See: https://creativecommons.org/licenses/by-nc-nd/4.0/.

\section{References}

1. Nunes ADDS, Silva CRL, Balen SA, et al. Prevalence of hearing impairment and associated factors in schoolaged children and adolescents: a systematic review. Braz J Otorhinolaryngol 2019;85:244-53. 


\section{Page 10 of 16}

2. Muñoz K, Baughman K, Meibos A, et al. Psychosocial Well-Being of Adults Who Are Deaf or Hard of Hearing. J Am Acad Audiol 2021;32:83-9.

3. Sterkers O, Ferrary E, Amiel C. Production of inner ear fluids. Physiol Rev 1988;68:1083-128.

4. Payan P, Kossmann H, Watrin A, et al. Ionic composition of endolymph in teleosts: origin and importance of endolymph alkalinity. J Exp Biol 1997;200:1905-12.

5. Ekdale EG. Form and function of the mammalian inner ear. J Anat 2016;228:324-37.

6. Lanvers-Kaminsky C, Zehnhoff-Dinnesen AA, Parfitt R, et al. Drug-induced ototoxicity: Mechanisms, Pharmacogenetics, and protective strategies. Clin Pharmacol Ther 2017;101:491-500.

7. Dallos P, Cheatham MA. Production of cochlear potentials by inner and outer hair cells. J Acoust Soc Am 1976;60:510-2.

8. McMahon CM, Patuzzi RB, Gibson WP, et al. Frequencyspecific electrocochleography indicates that presynaptic and postsynaptic mechanisms of auditory neuropathy exist. Ear Hear 2008;29:314-25.

9. Zheng XY, Ding DL, McFadden SL, et al. Evidence that inner hair cells are the major source of cochlear summating potentials. Hear Res 1997;113:76-88.

10. Durrant JD, Wang J, Ding DL, et al. Are inner or outer hair cells the source of summating potentials recorded from the round window? J Acoust Soc Am 1998;104:370-7.

11. Brown DJ, Patuzzi RB. Evidence that the compound action potential (CAP) from the auditory nerve is a stationary potential generated across dura mater. Hear Res 2010;267:12-26.

12. Brown AM, McDowell B, Forge A. Acoustic distortion products can be used to monitor the effects of chronic gentamicin treatment. Hear Res 1989;42:143-56.

13. Melcher JR, Kiang NY. Generators of the brainstem auditory evoked potential in cat. III: Identified cell populations. Hear Res 1996;93:52-71.

14. Harrison RV, Konomi U, Kanotra S, et al. Postnatal maturation of contralateral DPOAE suppression in a precocious animal model (chinchilla) of the human neonate. Acta Otolaryngol 2013;133:383-9.

15. Li J, Chen Y, Zeng S, et al. Contralateral Suppression of DPOAEs in Mice after Ouabain Treatment. Neural Plast 2018;2018:6890613.

16. Pouyatos B, Campo P, Lataye R. Use of DPOAEs for assessing hearing loss caused by styrene in the rat. Hear Res 2002;165:156-64.
Lin et al. Animal models of drug-induced sensorinueral hearing loss

17. Alvarado JC, Fuentes-Santamaría V, Jareño-Flores T, et al. Normal variations in the morphology of auditory brainstem response (ABR) waveforms: a study in Wistar rats. Neurosci Res 2012;73:302-11.

18. Dille MF, Ellingson RM, McMillan GP, et al. ABR obtained from time-efficient train stimuli for cisplatin ototoxicity monitoring. J Am Acad Audiol 2013;24:769-81.

19. Hatzopoulos S, Petruccelli J, Laurell G, et al. Ototoxic effects of cisplatin in a Sprague-Dawley rat animal model as revealed by $\mathrm{ABR}$ and transiently evoked otoacoustic emission measurements. Hear Res 2002;170:70-82.

20. Zheng QY, Johnson KR, Erway LC. Assessment of hearing in 80 inbred strains of mice by ABR threshold analyses. Hear Res 1999;130:94-107.

21. Aran JM, Erre JP, Lima da Costa D, et al. Acute and chronic effects of aminoglycosides on cochlear hair cells. Ann N Y Acad Sci 1999;884:60-8.

22. Parravicini L, Arpini A, Bamonte F, et al. Comparative ototoxicity of amikacin, gentamicin, netilmicin, and tobramycin in guinea pigs. Toxicol Appl Pharmacol 1982;65:222-30.

23. Kitasato I, Yokota M, Inouye S, et al. Comparative ototoxicity of ribostamycin, dactimicin, dibekacin, kanamycin, amikacin, tobramycin, gentamicin, sisomicin and netilmicin in the inner ear of guinea pigs. Chemotherapy 1990;36:155-68.

24. Huang MY, Schacht J. Drug-induced ototoxicity. Pathogenesis and prevention. Med Toxicol Adverse Drug Exp 1989;4:452-67.

25. Ahmed RM, Hannigan IP, MacDougall HG, et al. Gentamicin ototoxicity: a 23-year selected case series of 103 patients. Med J Aust 2012;196:701-4.

26. Matz GJ. Aminoglycoside cochlear ototoxicity. Otolaryngol Clin North Am 1993;26:705-12.

27. Dai CF, Steyger PS. A systemic gentamicin pathway across the stria vascularis. Hear Res 2008;235:114-24.

28. Marcotti W, van Netten SM, Kros CJ. The aminoglycoside antibiotic dihydrostreptomycin rapidly enters mouse outer hair cells through the mechano-electrical transducer channels. J Physiol 2005;567:505-21.

29. Makabe A, Kawashima Y, Sakamaki Y, et al. Systemic Fluorescent Gentamicin Enters Neonatal Mouse Hair Cells Predominantly Through Sensory Mechanoelectrical Transduction Channels. J Assoc Res Otolaryngol 2020;21:137-49.

30. Sha SH, Schacht J. Stimulation of free radical formation by aminoglycoside antibiotics. Hear Res 1999;128:112-8. 
31. Brenner D, Mak TW. Mitochondrial cell death effectors. Curr Opin Cell Biol 2009;21:871-7.

32. Jiang M, Taghizadeh F, Steyger PS. Potential Mechanisms Underlying Inflammation-Enhanced AminoglycosideInduced Cochleotoxicity. Front Cell Neurosci 2017;11:362.

33. Schacht J. Biochemical basis of aminoglycoside ototoxicity. Otolaryngol Clin North Am 1993;26:845-56.

34. Henry KR, Chole RA, McGinn MD, et al. Increased ototoxicity in both young and old mice. Archives of otolaryngology (Chicago, Ill : 1960) 1981;107:92-5.

35. Wu WJ, Sha SH, McLaren JD, et al. Aminoglycoside ototoxicity in adult CBA, C57BL and BALB mice and the Sprague-Dawley rat. Hear Res 2001;158:165-78.

36. Henley CM, Weatherly RA, Ou CN, et al. Pharmacokinetics of kanamycin in the developing rat. Hear Res 1996;99:85-90.

37. Uhl EW, Warner NJ. Mouse Models as Predictors of Human Responses: Evolutionary Medicine. Curr Pathobiol Rep 2015;3:219-23.

38. Schweitzer VG, Hawkins JE, Lilly DJ, et al. Ototoxic and nephrotoxic effects of combined treatment with cisdiamminedichloroplatinum and kanamycin in the guinea pig. Otolaryngol Head Neck Surg 1984;92:38-49.

39. Taylor RR, Nevill G, Forge A. Rapid hair cell loss: a mouse model for cochlear lesions. J Assoc Res Otolaryngol 2008;9:44-64.

40. Bethesda. Loop Diuretics. 2017.

41. Ding D, McFadden SL, Woo JM, et al. Ethacrynic acid rapidly and selectively abolishes blood flow in vessels supplying the lateral wall of the cochlea. Hear Res 2002;173:1-9.

42. Abbas L, Rivolta MN. Aminoglycoside ototoxicity and hair cell ablation in the adult gerbil: A simple model to study hair cell loss and regeneration. Hear Res 2015;325:12-26.

43. Kong WJ, Yin ZD, Fan GR, et al. Time sequence of auditory nerve and spiral ganglion cell degeneration following chronic kanamycin-induced deafness in the guinea pig. Brain Res 2010;1331:28-38.

44. Horvath L, Bächinger D, Honegger T, et al. Functional and morphological analysis of different aminoglycoside treatment regimens inducing hearing loss in mice. Exp Ther Med 2019;18:1123-30.

45. Bächinger D, Horvath L, Eckhard A, et al. Neuronal erythropoietin overexpression is protective against kanamycin-induced hearing loss in mice. Toxicol Lett 2018;291:121-8.

46. Deng X, Liu Z, Li X, et al. Generation of new hair cells by
DNA methyltransferase (Dnmt) inhibitor 5-azacytidine in a chemically-deafened mouse model. Sci Rep 2019;9:7997.

47. García-Alcántara F, Murillo-Cuesta S, Pulido S, et al. The expression of oxidative stress response genes is modulated by a combination of resveratrol and $\mathrm{N}$-acetylcysteine to ameliorate ototoxicity in the rat cochlea. Hear Res 2018;358:10-21.

48. Havenith S, Klis SF, Versnel H, et al. A guinea pig model of selective severe high-frequency hearing loss. Otol Neurotol 2013;34:1510-8.

49. Hirose K, Sato E. Comparative analysis of combination kanamycin-furosemide versus kanamycin alone in the mouse cochlea. Hear Res 2011;272:108-16.

50. Chen L, Xiong S, Liu Y, et al. Effect of different gentamicin dose on the plasticity of the ribbon synapses in cochlear inner hair cells of C57BL/6J mice. Mol Neurobiol 2012;46:487-94.

51. Ding D, Jiang H, Salvi RJ. Mechanisms of rapid sensory hair-cell death following co-administration of gentamicin and ethacrynic acid. Hear Res 2010;259:16-23.

52. Heinrich UR, Strieth S, Schmidtmann I, et al. Gentamicin alters Akt-expression and its activation in the guinea pig cochlea. Neuroscience 2015;311:490-8.

53. Robinson AM, Vujanovic I, Richter CP. Minocycline protection of neomycin induced hearing loss in gerbils. Biomed Res Int 2015;2015:934158.

54. Bayindir T, Filiz A, Iraz M, et al. Evaluation of the protective effect of Beta glucan on amikacin ototoxicity using distortion product otoacoustic emission measurements in rats. Clin Exp Otorhinolaryngol 2013;6:1-6.

55. Cavaletti G, Bogliun G, Crespi V, et al. Neurotoxicity and ototoxicity of cisplatin plus paclitaxel in comparison to cisplatin plus cyclophosphamide in patients with epithelial ovarian cancer. J Clin Oncol 1997;15:199-206.

56. Lu J, Wang W, Liu H, et al. Cisplatin induces calcium ion accumulation and hearing loss by causing functional alterations in calcium channels and exocytosis. Am J Transl Res 2019;11:6877-89.

57. Soyalıç H, Gevrek F, Koç S, et al. Intraperitoneal curcumin and vitamin $\mathrm{E}$ combination for the treatment of cisplatininduced ototoxicity in rats. Int J Pediatr Otorhinolaryngol 2016;89:173-8.

58. Waissbluth S, Salehi P, He X, et al. Systemic dexamethasone for the prevention of cisplatin-induced ototoxicity. Eur Arch Otorhinolaryngol 2013;270:1597-605.

59. Fernandez R, Harrop-Jones A, Wang X, et al. The Sustained-Exposure Dexamethasone Formulation OTO- 
104 Offers Effective Protection against Cisplatin-Induced Hearing Loss. Audiol Neurootol 2016;21:22-9.

60. Harrison RT, Seiler BM, Bielefeld EC. Ototoxicity of $12 \mathrm{mg} / \mathrm{kg}$ cisplatin in the Fischer 344/NHsd rat using multiple dosing strategies. Anticancer Drugs 2016;27:780-6.

61. Husain K, Scott B, Whitworth C, et al. Time response of carboplatin-induced hearing loss in rat. Hear Res 2004;191:110-8.

62. Takeno S, Harrison RV, Ibrahim D, et al. Cochlear function after selective inner hair cell degeneration induced by carboplatin. Hear Res 1994;75:93-102.

63. Wake M, Takeno S, Ibrahim D, et al. Selective inner hair cell ototoxicity induced by carboplatin. Laryngoscope 1994;104:488-93.

64. El-Badry MM, McFadden SL. Electrophysiological correlates of progressive sensorineural pathology in carboplatin-treated chinchillas. Brain Res 2007;1134:122-30.

65. Santos NAGD, Ferreira RS, Santos ACD. Overview of cisplatin-induced neurotoxicity and ototoxicity, and the protective agents. Food Chem Toxicol 2020;136:111079.

66. Waissbluth S, Daniel SJ. Cisplatin-induced ototoxicity: transporters playing a role in cisplatin toxicity. Hear Res 2013;299:37-45

67. Gentilin E, Simoni E, Candito M, et al. Cisplatin-Induced Ototoxicity: Updates on Molecular Targets. Trends Mol Med 2019;25:1123-32.

68. Ding DL, Wang J, Salvi R, et al. Selective loss of inner hair cells and type-I ganglion neurons in carboplatintreated chinchillas. Mechanisms of damage and protection. Ann N Y Acad Sci 1999;884:152-70.

69. DeBacker JR, Harrison RT, Bielefeld EC. Cisplatininduced threshold shift in the CBA/CaJ, C57BL/6J, $\mathrm{BALB} / \mathrm{cJ}$ mouse models of hearing loss. Hear Res 2020;387:107878.

70. Bielefeld EC, Markle A, DeBacker JR, et al. Chronotolerance for cisplatin ototoxicity in the rat. Hear Res 2018;370:16-21.

71. Tserga E, Moreno-Paublete R, Sarlus H, et al. Circadian vulnerability of cisplatin-induced ototoxicity in the cochlea. FASEB J 2020;34:13978-92.

72. DeBacker JR, Harrison RT, Bielefeld EC. Long-Term Synergistic Interaction of Cisplatin- and Noise-Induced Hearing Losses. Ear Hear 2017;38:282-91.

73. Xia L, Chen Z, Su K, et al. Comparison of cochlear cell death caused by cisplatin, alone and in combination with furosemide. Toxicol Pathol 2014;42:376-85.

74. Gersten BK, Fitzgerald TS, Fernandez KA, et al. Ototoxicity and Platinum Uptake Following Cyclic Administration of Platinum-Based Chemotherapeutic Agents. J Assoc Res Otolaryngol 2020;21:303-21.

75. Husain K, Scott RB, Whitworth C, et al. Dose response of carboplatin-induced hearing loss in rats: antioxidant defense system. Hear Res 2001;151:71-8.

76. Hofstetter P, Ding D, Salvi R. Magnitude and pattern of inner and outer hair cell loss in chinchilla as a function of carboplatin dose. Audiology 1997;36:301-11.

77. Lobarinas E, Salvi R, Ding D. Selective Inner Hair Cell Dysfunction in Chinchillas Impairs Hearing-in-Noise in the Absence of Outer Hair Cell Loss. J Assoc Res Otolaryngol 2016;17:89-101.

78. Lobarinas E, Salvi R, Ding D. Gap Detection Deficits in Chinchillas with Selective Carboplatin-Induced Inner Hair Cell Loss. J Assoc Res Otolaryngol 2020;21:475-83.

79. Reyes S, Ding D, Sun W, et al. Effect of inner and outer hair cell lesions on electrically evoked otoacoustic emissions. Hear Res 2001;158:139-50.

80. El-Badry MM, McFadden SL. Evaluation of inner hair cell and nerve fiber loss as sufficient pathologies underlying auditory neuropathy. Hear Res 2009;255:84-90.

81. Salvi R, Sun W, Ding D, et al. Inner Hair Cell Loss Disrupts Hearing and Cochlear Function Leading to Sensory Deprivation and Enhanced Central Auditory Gain. Front Neurosci 2017;10:621.

82. Carvalho C, Santos RX, Cardoso S, et al. Doxorubicin: the good, the bad and the ugly effect. Curr Med Chem 2009;16:3267-85.

83. England JD, Rhee EK, Said G, et al. Schwann cell degeneration induced by doxorubicin (adriamycin). Brain 1988;111:901-13.

84. El-Badry MM, Ding DL, McFadden SL, et al. Physiological effects of auditory nerve myelinopathy in chinchillas. Eur J Neurosci 2007;25:1437-46.

85. Starr A, Picton TW, Sininger Y, et al. Auditory neuropathy. Brain 1996;119:741-53.

86. Starr A, Sininger Y, Nguyen T, et al. Cochlear receptor (microphonic and summating potentials, otoacoustic emissions) and auditory pathway (auditory brain stem potentials) activity in auditory neuropathy. Ear Hear 2001;22:91-9.

87. Starr A, Sininger YS, Pratt H. The varieties of auditory neuropathy. J Basic Clin Physiol Pharmacol 2000;11:215-30.

88. Abbate C, Giorgianni C, Munaò F, et al. Neurotoxicity 
induced by exposure to toluene. An electrophysiologic study. Int Arch Occup Environ Health 1993;64:389-92.

89. Rybak LP. Hearing: the effects of chemicals. Otolaryngol Head Neck Surg 1992;106:677-86.

90. Campo P, Lataye R, Cossec B, et al. Toluene-induced hearing loss: a mid-frequency location of the cochlear lesions. Neurotoxicol Teratol 1997;19:129-40.

91. Cappaert NL, Klis SF, Muijser H, et al. The ototoxic effects of ethyl benzene in rats. Hear Res 1999;137:91-102.

92. Campo P, Lataye R, Loquet G, et al. Styreneinduced hearing loss: a membrane insult. Hear Res 2001;154:170-80.

93. Gagnaire F, Langlais C. Relative ototoxicity of 21 aromatic solvents. Arch Toxicol 2005;79:346-54.

94. Sullivan MJ, Rarey KE, Conolly RB. Ototoxicity of toluene in rats. Neurotoxicol Teratol 1988;10:525-30.

95. Lataye R, Campo P, Loquet G. Toluene ototoxicity in rats: assessment of the frequency of hearing deficit by electrocochleography. Neurotoxicol Teratol 1999;21:267-76.

96. Loquet G, Campo P, Lataye R. Comparison of tolueneinduced and styrene-induced hearing losses. Neurotoxicol Teratol 1999;21:689-97.

97. Crofton KM, Lassiter TL, Rebert CS. Solvent-induced ototoxicity in rats: an atypical selective mid-frequency hearing deficit. Hear Res 1994;80:25-30.

98. Cappaert NL, Klis SF, Baretta AB, et al. Ethyl benzeneinduced ototoxicity in rats: a dose-dependent midfrequency hearing loss. J Assoc Res Otolaryngol 2000;1:292-9.

99. Davis RR, Murphy WJ, Snawder JE, et al. Susceptibility to the ototoxic properties of toluene is species specific. Hear Res 2002;166:24-32.

100.Monks TJ, Ghersi-Egea JF, Philbert M, et al. Symposium overview: the role of glutathione in neuroprotection and neurotoxicity. Toxicol Sci 1999;51:161-77.

101.PubChem. Ouabain. 2021. Available online: https://www. ncbi.nlm.nih.gov/pubmed/

102.McLean WJ, Smith KA, Glowatzki E, et al. Distribution of the Na,K-ATPase alpha subunit in the rat spiral ganglion and organ of corti. J Assoc Res Otolaryngol 2009;10:37-49.

103. Newton K. RIPK1 and RIPK3: critical regulators of inflammation and cell death. Trends Cell Biol 2015;25:347-53.

104.Lang H, Schulte BA, Schmiedt RA. Ouabain induces apoptotic cell death in type I spiral ganglion neurons, but not type II neurons. J Assoc Res Otolaryngol
$2005 ; 6: 63-74$.

105.Schmiedt RA, Okamura HO, Lang H, et al. Ouabain application to the round window of the gerbil cochlea: a model of auditory neuropathy and apoptosis. J Assoc Res Otolaryngol 2002;3:223-33.

106. Lee MY, Bae SH, Chang SY, et al. Photobiomodulation by laser therapy rescued auditory neuropathy induced by ouabain. Neurosci Lett 2016;633:165-73.

107.Hamada M, Kimura RS. Morphological changes induced by administration of a $\mathrm{Na}+\mathrm{K}+-\mathrm{ATP}$ ase inhibitor in normal and hydropic inner ears of the guinea pig. Acta Otolaryngol 1999;119:778-86.

108. Schomann T, Ramekers D, de Groot JCMJ, et al. Ouabain Does Not Induce Selective Spiral Ganglion Cell Degeneration in Guinea Pigs. Biomed Res Int 2018;2018:1568414.

109. Silva E, Soares-da-Silva P. New insights into the regulation of $\mathrm{Na}+\mathrm{K}+-\mathrm{ATP} a \mathrm{se}$ by ouabain. Int Rev Cell Mol Biol 2012;294:99-132.

110. Rask-Andersen H, Schrott-Fischer A, Pfaller K, et al. Perilymph/modiolar communication routes in the human cochlea. Ear Hear 2006;27:457-65.

111. Wang X, Mao X, Liang K, et al. RIP3-mediated necroptosis was essential for spiral ganglion neuron damage. Neurosci Lett 2021;744:135565.

112.Pujol R, Puel JL, Gervais d'Aldin C, et al. Pathophysiology of the glutamatergic synapses in the cochlea. Acta Otolaryngol 1993;113:330-4.

113. Rothman SM. The neurotoxicity of excitatory amino acids is produced by passive chloride influx. J Neurosci 1985;5:1483-9.

114. Ruel J, Bobbin RP, Vidal D, et al. The selective AMPA receptor antagonist GYKI 53784 blocks action potential generation and excitotoxicity in the guinea pig cochlea. Neuropharmacology 2000;39:1959-73.

115. Steinbach S, Lutz J. Glutamate induces apoptosis in cultured spiral ganglion explants. Biochem Biophys Res Commun 2007;357:14-9.

116.Ding ZJ, Chen X, Tang XX, et al. Apoptosis-inducing factor and calpain upregulation in glutamate-induced injury of rat spiral ganglion neurons. Mol Med Rep 2015;12:1685-92.

117.Sun H, Hashino E, Ding DL, et al. Reversible and irreversible damage to cochlear afferent neurons by kainic acid excitotoxicity. J Comp Neurol 2001;430:172-81.

118.Zheng XY, Henderson D, Hu BH, et al. Recovery of structure and function of inner ear afferent synapses following kainic acid excitotoxicity. Hear Res 
1997;105:65-76.

119. Juiz JM, Rueda J, Merchán JA, et al. The effects of kainic acid on the cochlear ganglion of the rat. Hear Res 1989;40:65-74.

120.Henry KS, Abrams KS. Persistent Auditory Nerve Damage Following Kainic Acid Excitotoxicity in the Budgerigar (Melopsittacus undulatus). J Assoc Res Otolaryngol 2018;19:435-49.

121. Gould S, Scott RC. 2-Hydroxypropyl-beta-cyclodextrin (HP-beta-CD): a toxicology review. Food Chem Toxicol 2005;43:1451-9.

122.Dass CR, Jessup W. Apolipoprotein A-I, cyclodextrins and liposomes as potential drugs for the reversal of atherosclerosis. A review. J Pharm Pharmacol 2000;52:731-61.

123. Oliveri V, Vecchio G. Cyclodextrins as Protective Agents of Protein Aggregation: An Overview. Chem Asian J 2016;11:1648-57.

124. Ottinger EA, Kao ML, Carrillo-Carrasco N, et al. Collaborative development of 2-hydroxypropyl- $\beta$ cyclodextrin for the treatment of Niemann-Pick type C1 disease. Curr Top Med Chem 2014;14:330-9.

125. Ward S, O'Donnell P, Fernandez S, et al. 2-hydroxypropylbeta-cyclodextrin raises hearing threshold in normal cats and in cats with Niemann-Pick type C disease. Pediatr Res 2010;68:52-6.

126. Ory DS, Ottinger EA, Farhat NY, et al. Intrathecal 2-hydroxypropyl- $\beta$-cyclodextrin decreases neurological disease progression in Niemann-Pick disease, type C1: a non-randomised, open-label, phase 1-2 trial. Lancet 2017;390:1758-68.

127. Crumling MA, Liu L, Thomas PV, et al. Hearing loss and hair cell death in mice given the cholesterolchelating agent hydroxypropyl- $\beta$-cyclodextrin. PLoS One 2012;7:e53280.

128. Ding D, Manohar S, Jiang H, et al. Hydroxypropyl- $\beta$ cyclodextrin causes massive damage to the developing auditory and vestibular system. Hear Res 2020;396:108073.

129. Ding D, Jiang H, Salvi R. Cochlear spiral ganglion neuron degeneration following cyclodextrin-induced hearing loss. Hear Res 2021;400:108125.

130.Liu X, Ding D, Chen GD, et al. 2-Hydroxypropyl- $\beta$ cyclodextrin Ototoxicity in Adult Rats: Rapid Onset and Massive Destruction of Both Inner and Outer Hair Cells Above a Critical Dose. Neurotox Res 2020;38:808-23.

131. Ashmore J. Cochlear outer hair cell motility. Physiol Rev 2008;88:173-210.

132. Takahashi S, Homma K, Zhou Y, et al. Susceptibility of outer hair cells to cholesterol chelator 2-hydroxypropyl- $\beta$ cyclodextrine is prestin-dependent. Sci Rep 2016;6:21973.

133.Zhou Y, Takahashi S, Homma K, et al. The susceptibility of cochlear outer hair cells to cyclodextrin is not related to their electromotile activity. Acta Neuropathol Commun 2018;6:98.

134. Agirdir BV, Bilgen I, Dinc O, et al. Effect of zinc ion on cadmium-induced auditory changes. Biol Trace Elem Res 2002;88:153-63.

135. Kim SJ, Jeong HJ, Myung NY, et al. The protective mechanism of antioxidants in cadmium-induced ototoxicity in vitro and in vivo. Environ Health Perspect 2008;116:854-62.

136.Pinilla-Tenas JJ, Sparkman BK, Shawki A, et al. Zip14 is a complex broad-scope metal-ion transporter whose functional properties support roles in the cellular uptake of zinc and nontransferrin-bound iron. Am J Physiol Cell Physiol 2011;301:C862-71.

137. Ozcaglar HU, Agirdir B, Dinc O, et al. Effects of cadmium on the hearing system. Acta Otolaryngol 2001;121:393-7.

138. Ding D, Roth J, Salvi R. Manganese is toxic to spiral ganglion neurons and hair cells in vitro. Neurotoxicology 2011;32:233-41.

139.Li P, Ding D, Salvi R, et al. Cobalt-Induced Ototoxicity in Rat Postnatal Cochlear Organotypic Cultures. Neurotox Res 2015;28:209-21.

140. Garrick MD, Singleton ST, Vargas F, et al. DMT1: which metals does it transport? Biol Res 2006;39:79-85.

141. Wang CY, Jenkitkasemwong S, Duarte S, et al. ZIP8 is an iron and zinc transporter whose cell-surface expression is up-regulated by cellular iron loading. J Biol Chem 2012;287:34032-43.

142.Ding D, Salvi R, Roth JA. Cellular localization and developmental changes of the different isoforms of divalent metal transporter 1 (DMT1) in the inner ear of rats. Biometals 2014;27:125-34.

143.Ding D, Salvi R, Roth JA. Cellular localization and developmental changes of Zip8, Zip14 and transferrin receptor 1 in the inner ear of rats. Biometals 2014;27:731-44.

144. Roth J, Ponzoni S, Aschner M. Manganese homeostasis and transport. Met Ions Life Sci 2013;12:169-201.

145. Wang Q, Luo W, Zhang W, et al. Involvement of DMT1 +IRE in the transport of lead in an in vitro BBB model. Toxicol In Vitro 2011;25:991-8.

146. Gavin CE, Gunter KK, Gunter TE. Manganese and calcium efflux kinetics in brain mitochondria. Relevance to manganese toxicity. Biochem J 1990;266:329-34. 
147. Martinez-Finley EJ, Gavin CE, Aschner M, et al. Manganese neurotoxicity and the role of reactive oxygen species. Free Radic Biol Med 2013;62:65-75.

148. Sousa CA, Soares EV. Mitochondria are the main source and one of the targets of $\mathrm{Pb}$ (lead)-induced oxidative stress in the yeast Saccharomyces cerevisiae. Appl Microbiol Biotechnol 2014;98:5153-60.

149. Wang W, Li D, Ding X, et al. N-Acetylcysteine protects inner ear hair cells and spiral ganglion neurons from manganese exposure by regulating ROS levels. Toxicol Lett 2017;279:77-86.

150.Anniko M, Sarkady L. Cochlear pathology following exposure to mercury. Acta Otolaryngol 1978;85:213-24.

151.Xue-wen W, Da-lian D, Hong S, et al. Lead neurotoxicity in rat cochlear organotypic cultures. Journal of Otology 2011;6:43-50.

152. Whitworth CA, Hudson TE, Rybak LP. The effect of combined administration of cadmium and furosemide on auditory function in the rat. Hear Res 1999;129:61-70.

153. Carlson K, Schacht J, Neitzel RL. Assessing ototoxicity due to chronic lead and cadmium intake with and without noise exposure in the mature mouse. J Toxicol Environ Health A 2018;81:1041-57.

154. Muthaiah VPK, Chen GD, Ding D, et al. Effect of manganese and manganese plus noise on auditory function and cochlear structures. Neurotoxicology 2016;5 5:65-73.

155. Chuu JJ, Hsu CJ, Lin-Shiau SY. Abnormal auditory brainstem responses for mice treated with mercurial compounds: involvement of excessive nitric oxide. Toxicology 2001;162:11-22.

156.Jamesdaniel S, Rosati R, Westrick J, et al. Chronic lead exposure induces cochlear oxidative stress and potentiates noise-induced hearing loss. Toxicol Lett 2018;292:175-80.

157.Liu S, Zhang K, Wu S, et al. Lead-induced hearing loss in rats and the protective effect of copper. Biol Trace Elem Res 2011;144:1112-9.

158. Liu X, Zheng G, Wu Y, et al. Lead exposure results in hearing loss and disruption of the cochlear blood-labyrinth barrier and the protective role of iron supplement. Neurotoxicology 2013;39:173-81.

159. Soons JA, Ricci AJ, Steele CR, et al. Cytoarchitecture of the mouse organ of corti from base to apex, determined using in situ two-photon imaging. J Assoc Res Otolaryngol 2015;16:47-66.

160. Taberner AM, Liberman MC. Response properties of single auditory nerve fibers in the mouse. J Neurophysiol 2005;93:557-69.

161.Johnson SL, Marcotti W. Biophysical properties of CaV1.3 calcium channels in gerbil inner hair cells. J Physiol 2008;586:1029-42.

162. Miller JD. Audibility curve of the chinchilla. J Acoust Soc Am 1970;48:513-23.

163. WEVER EG, VERNON JA, PETERSON EA. The highfrequency sensitivity of the guinea pig ear. Proc Natl Acad Sci U S A 1963;49:319-22.

164.Heffner HE, Heffner RS. Hearing ranges of laboratory animals. J Am Assoc Lab Anim Sci 2007;46:20-2.

165.Stamataki S, Francis HW, Lehar M, et al. Synaptic alterations at inner hair cells precede spiral ganglion cell loss in aging C57BL/6J mice. Hear Res 2006;221:104-18.

166. Hunter KP, Willott JF. Aging and the auditory brainstem response in mice with severe or minimal presbycusis. Hear Res 1987;30:207-18.

167.Willott JF. Effects of aging, hearing loss, and anatomical location on thresholds of inferior colliculus neurons in C57BL/6 and CBA mice. J Neurophysiol 1986;56:391-408.

168. Li HS. Influence of genotype and age on acute acoustic trauma and recovery in CBA/Ca and C57BL/6J mice. Acta Otolaryngol 1992;112:956-67.

169. Li HS, Borg E. Age-related loss of auditory sensitivity in two mouse genotypes. Acta Otolaryngol 1991;111:827-34.

170. Parham K, Willott JF. Acoustic startle response in young and aging C57BL/6J and CBA/J mice. Behav Neurosci 1988;102:881-6.

171. White JA, Burgess BJ, Hall RD, et al. Pattern of degeneration of the spiral ganglion cell and its processes in the C57BL/6J mouse. Hear Res 2000;141:12-8.

172. Sha SH, Kanicki A, Dootz G, et al. Age-related auditory pathology in the CBA/J mouse. Hear Res 2008;243:87-94.

173. Liberman MC, Tartaglini E, Fleming JC, et al. Deletion of SLC19A2, the high affinity thiamine transporter, causes selective inner hair cell loss and an auditory neuropathy phenotype. J Assoc Res Otolaryngol 2006;7:211-7.

174.Hayward T, Young A, Jiang A, et al. Glucococorticoid receptor activation exacerbates aminoglycosideinduced damage to the zebrafish lateral line. Hear Res 2019;377:12-23.

175.MacRae CA, Peterson RT. Zebrafish as tools for drug discovery. Nat Rev Drug Discov 2015;14:721-31.

176.Zon LI, Peterson RT. In vivo drug discovery in the zebrafish. Nat Rev Drug Discov 2005;4:35-44.

177. Borkholder DA, Zhu X, Frisina RD. Round window membrane intracochlear drug delivery enhanced by induced advection. J Control Release 2014;174:171-6.

178. Stevens SM, Brown LN, Ezell PC, et al. The Mouse 
Round-window Approach for Ototoxic Agent Delivery: A Rapid and Reliable Technique for Inducing Cochlear Cell Degeneration. J Vis Exp 2015;(105):53131.

179. Cai L, Stomackin G, Perez NM, et al. Recovery

from tympanic membrane perforation: Effects on

Cite this article as: Lin $\mathrm{X}$, Luo J, Tan J, Yang L, Wang M, Li P. Experimental animal models of drug-induced sensorineural hearing loss: a narrative review. Ann Transl Med 2021;9(17):1393. doi: 10.21037/atm-21-2508 membrane thickness, auditory thresholds, and middle ear transmission. Hear Res 2019;384:107813.

(English Language Editors: B. Maizey and J. Chapnick) 